\title{
生体内けい骨の動特性とモデル化に関する研究*
}

\author{
佐 藤 秀 紀*1, 岩 田 佳 雄*1 \\ 谷口文朗*2, 吉 野修 -*2
}

\section{Dynamic Characteristics and Modeling of In-Vivo Tibia}

\author{
Hidenori SATO, Yoshio IWATA, \\ Fumio TANIGUCHI and Syuuichi YOSHINO
}

\begin{abstract}
A three-dimensional FEM analysis and human in-vivo tibia experiment were carried out for the diagnosis of bone diseases such as osteoporosis by using vibration. The natural frequency and the equivalent stiffness, which are obtained by circle fitting of the mobility transfer function of in-vivo tibia, were used as evaluation parameters for the diagnosis. The results of the osteoporosis simulation by FEM showed that the stiffness is more sensitive to the change in the bone physical property than the natural frequency. The transfer function of in-vivo tibia was measured for 155 men and women by random excitation. Both the natural frequency and the stiffness, which are normalized by the length of the tibia, decreased with aging on average, with the stiffness showing the more marked trend. In women, these evaluation parameters showed lower values throughout the age range than those of men, and the stiffness reduction with aging was larger.
\end{abstract}

Key Words: Medical Engineering, Vibration, Identification, Bone, In-Vivo Tibia, Modeling, FEM, Modal Analysis, Osteoporosis Diagnosis

\section{1. 緒}

近年, 急速な高齢化社会の出現に伴い, 骨組織の強 度劣化による骨折を引き起こす骨粗しょう症が問題と なってきている，現在のところ，骨の劣化を診断する ためには $\gamma$ 線による骨塩量の測定などが行われてい るが(1)，装置が大がかりで高価である，今後多人数の 検診を実施するには簡便な手法・機器の開発が望まれ る.本研究は，体外より振動を与光，その動的応答より 骨の状態診断（骨折治ゆ，強度劣化など）を行う手法の 可能性を検討するため，その基整的研究を試みたもの である．振動応答による診断は計測時間が短く，装置 が簡便・安価である特色を持つ。

このような手法に関係するこれまでの主な研究を上 げると，Jurist ら (2) は生体前腕尺骨に振動を与え固有 振動数を検出し，加秢とともに固有振動数が低下する ことを示している. Doherty ${ }^{(3)}$ は少数ではあるがけい 骨標本の強制振動応答より固有振動数, 剛性を求め固 有振動数より剛性のほうが骨劣化には敏感であること を示唆している。また，Perre ら ${ }^{(4)(5)}$ は解剖および簡単

* 原稿受付 1994 年 11 月 17 日.

*1 正員, 金沢大学工学部（\$920 金沢市小立野 2-40-20)

*2 金沢大学大学院.
な FEM 解析によりヒトけい骨の振動特性に及ほす筋 肉, 関節の影響を調べ, 振動モードは生体内で両端自 由, 固有振動数は解剖の進行につれて高くなることを 明らかにしている.Ziegert ら(6)および Nokes ら(7)は 生体内骨の振動測定に及浑す他の生体組織および検出 器の影響を検討している。 また，三嶋ら ${ }^{(8)}$ は骨折回復 の診断に振動伝達特性の利用を試みている，以上，こ れまでの研究では骨少化のための評価パラメータとし ては生体内骨の場合主として固有振動数が取り上げら れてきた。しかし，評価パラメータの検討とその生体 測定による評価についてはまだ十分に研究されている とはいいがたい。

本論文ではこれまでの研究をふまえ，上卜けい骨を 対象として，FEM を用いた骨粗しょう症シミュレー ションによる骨の動特性解析と評価パラメー夕につい ての検討，およびそれに基づくほほ，健常者と思われ る人を対象に生体計測・解析を行い，生体内けい骨の 動的特性とそのモデル化について検討したものであ り，またこれらを通して振動応答による簡便な生体内 骨の状態診断の可能性について基礎的な研究を行った ものである. 


\section{2.ヒトけい骨の動特性計測}

生体内けい骨の動特性計測実験の概要を図 1 に示 す. 被験者は椅子に腰掛け, 左下肢の滕から下を力を 抜いた状態で垂らす．加振は実験者が手で押さえた小 形の動電形加振器によって被験者くるぶし(踝)を基本 矢状面に対し垂直方向に加振する. 加振機先端には力 変換器を取付け加振力を測定する。加振には $1000 \mathrm{~Hz}$ までのランダム波を用いる。応答検出には加速度ピッ クアップ $(2 \mathrm{~g}) を$ 用い, 振動モードを考慮して, けい骨 代表長さ (くるぶしとけい骨上端間の距離) $L$ の $1 / 2$ の前内側面の平坦部にサポータで固定した（図 2). 加 振力および加速度応答を FFT アナライザに取り込み, 伝達関数を求める。なお加速度ピックアップおよび加 振機の押付け条件については, 予備的実験を行い, デ ータが安定して得られる条件を決めて行った。

\section{3. 評 価 法}

実験により得られた生体内けい骨の伝達関数の例を モビリティの極座標表示(図 3 ) およびアクセレランス の実部と虚部(図 4)によって示した。これらから明ら かなように隇衰はかなり大きいものの，1 自由度系て 概略模擬できると考えられる。

骨の強度劣化に対する評価値としては Doherty ${ }^{(3)}$ らの結果を考虑して剛性 $k$, 固有振動数 $f_{n}$ を用いる.

これらを求める方法としては, モビリティ伝達関数

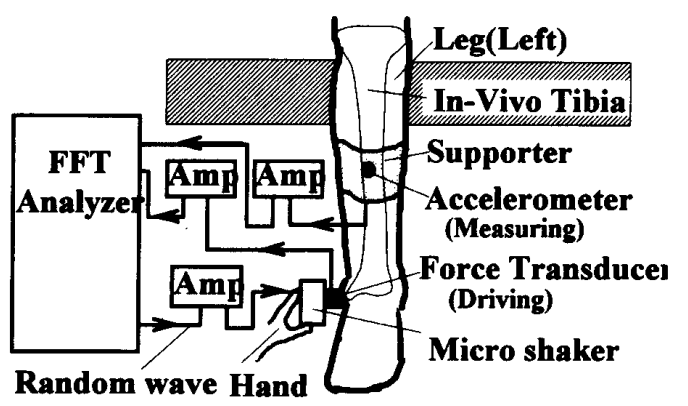

図 1 実験システム

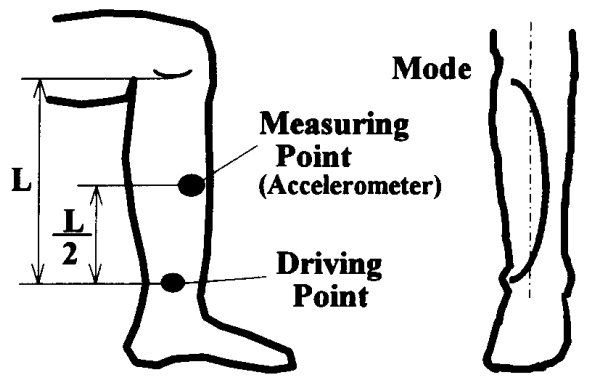

図 2 加振点と測定点, 生体内けい骨のモード
に対する，1自由度サークルフィット法によった。 1 自由度粘性隇衰系の運動方程式を次式で表す。

$$
m \ddot{x}+c \dot{x}+k x=F e^{j \omega t}
$$

複素定数を加えたモビリティ $G_{M}$ は次式で表される。

$$
\frac{V}{F}=\left(G_{M}\right)=\frac{1}{c+j(m \omega-k / \omega)}+Z_{R}+j Z_{I}
$$

ここに $V$ は複素速度振幅, $Z_{R}+j Z_{I}$ は補正項である. モビリティを実部 $\operatorname{Re}\left(G_{M}\right)$ ，虚部 $\operatorname{Im}\left(G_{M}\right)$ に分けると， ナイキスト線図上では中心が $\left(Z_{R}+1 / 2 c, Z_{I}\right)$ 半径が $(1 / 2 c)$ の円となることから, 最小二乗法により以下の 上うに $m, k, c$ を求める.

$$
\begin{aligned}
& \left(\begin{array}{l}
m \\
k
\end{array}\right)=\left(\begin{array}{cc}
\sum_{i=1}^{n} \omega_{i}^{2} & -n \\
-n & \sum_{i=1}^{n} \frac{1}{\omega_{i}^{2}}
\end{array}\right)^{-1}\left(\begin{array}{c}
\sum_{i=1}^{n} \operatorname{Im}\left(\frac{1}{G_{M}}\right) \times \omega_{i} \\
-\sum_{i=1}^{N} \operatorname{Im}\left(\frac{1}{G_{M}}\right) \times \frac{1}{\omega_{i}}
\end{array}\right) \\
& c=\frac{1}{n} \sum_{i=1}^{N} \operatorname{Re}\left(\frac{1}{G_{M}}\right) \cdots \cdots \ldots \ldots \ldots \ldots \ldots \ldots \ldots \ldots \ldots(3)
\end{aligned}
$$

ここで, $n$ は解析に用いるデー夕数である。

固有振動数 $f_{n}$ は $f_{n}=(1 / 2 \pi) \sqrt{k / m}$ より求められる.解 析範囲は図 4 に示すように一次固有振動数と考えられ

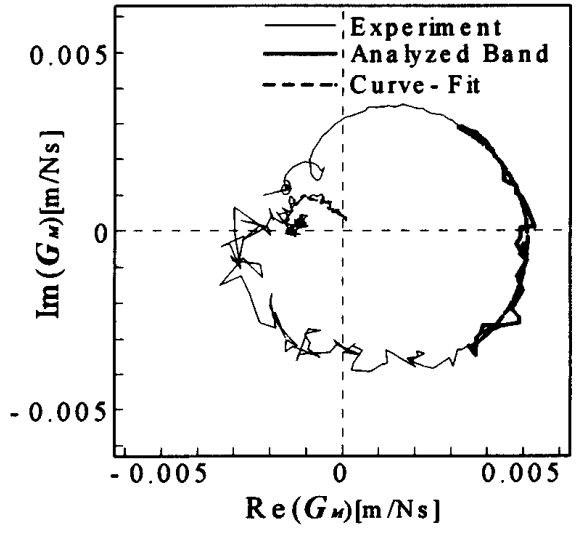

図 3 生体内けい骨のモビリティ・ナイキスト線図

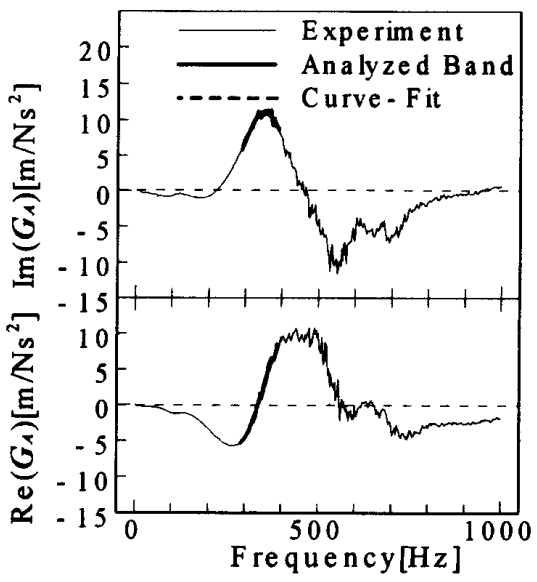

図 4 生体内けい骨の加速度コクアド線図 
るアクセレランス虚部のピーク前後 $100 \mathrm{~Hz}$ とした。

\section{FEM 解析による評価值の検討}

骨粗しょう症による骨の変化に対する評価値の変化 の傾向を調べるため, FEM 解析を用いた骨粗しょう 症シミュレーションを行った，手順としては，(1)骨の 多孔質率と等価特性值の関係をはりモデルを用いて求 める, (2)等価特性值を用いてけい骨 FEM モデルを作 成し, 動的解析を行って伝達関数を求める，(3)これに サークルフィットを行い, 評価値を算出する，またけ い骨長さによる評価値の変動とその補正についても検 討を行う。

$4 \cdot 1$ けい骨FEM モデル ある被験者のレント ゲン写真を基に，図 5 に示す要素数 1062 の三次元 FEM モデルを作成した。境界条件はこれまでに報告 されている(4)(5) ように生体内において両端自由とみな せることから, 同じく両端自由とした。けい骨は皮質

\section{表 1 骨組織の物性値( ${ }^{(9)}$}

\begin{tabular}{|c|c|c|c|}
\hline & $\left.\rho / \mathrm{kg} / \mathrm{m}^{\mathbf{3}}\right]$ & $E$ IGpa & $v$ \\
\hline Cortical bone & 2254 & 16.4 & 0.23 \\
\hline Spongy bone & 597 & 0.12 & 0.23 \\
\hline Bone marrow & 1227 & 0.0 & $\ldots$ \\
\hline
\end{tabular}

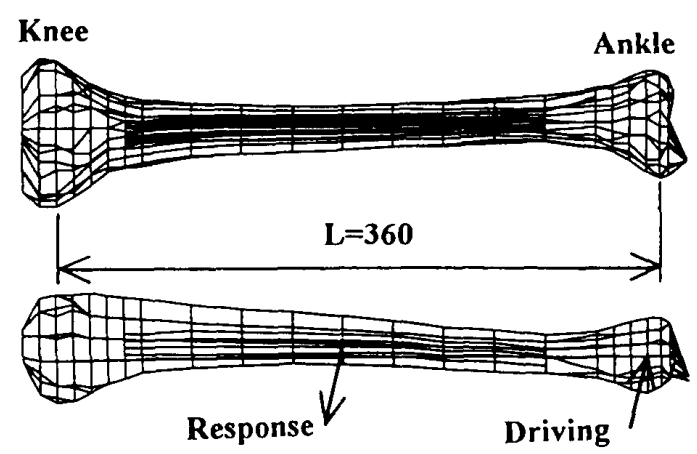

図 5 けい骨の FEM モデル

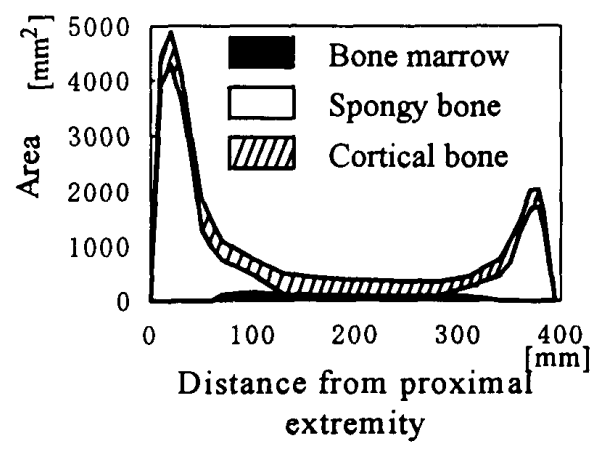

図 6 けい骨 FEM モデルの材質分布
骨(Cortical bone), 海綿骨(Spongy bone), 骨髄 (Bone marrow)の 3 種類から構成されるが, 本モデ ルではこれらの分布を Thomsen ${ }^{(9)}$ の骨質分布を参考 にし図 6 に示すように設定した。骨粗しょう症では， 骨質の多孔質化や幅・厚さの減少が起因して骨の劣化 が起こると考えられる(1). 以下では定性的傾向をみる ためけい骨剛性を主に受け持つ皮質骨の多孔質化によ クシミュレーションを行った。表 1 に解析に使用した Thomsenによる骨質の材料定数を示す。ここに $\rho$ は 密度, $E$ はヤング率, レはポアソン比である.

$4 \cdot 2$ 皮質骨の多孔澌化モデル骨粗しょう症で は皮質骨は多孔質化する，骨が多孔質化したときの等 価ヤング率, 等価密度を以下のように求めた。図 7 に 示すように皮質骨の物性を持つ両端自由はり FEM モ デル(要素数 600)において, ランダムに選択した空孔 要素の物性值(ヤング率, 密度)を, 骨髄液の物性値(空 孔に体液が入ると仮定)に置き換えた多孔質モデルを 考える. 全体積に対する空孔の体積割合から空孔率 $v_{f}$ を式(4)で定義する。

$$
v_{f}=(\text { 空孔の要素数 }) /(\text { 全要素数 }) \times 100 \quad[\%]
$$

等価密度 $\rho_{\mathrm{eq} v}$ は空孔率と各要素の密度の関係から 式 5 ) で算出する.

$$
\rho_{\mathrm{eq} v}=\left\{\rho_{\mathrm{cor}}\left(100-v_{f}\right)+\rho_{\mathrm{mar}} \cdot v_{f}\right\} / 100
$$

ここに, $\rho_{\text {cor }}=$ 皮質骨密度, $\rho_{\text {mar }}=$ 骨髄密度.

等価ヤング率 $E_{\mathrm{eq} v}$ は, FEMによりこのはりの固 有值解析を行い, 得られた一次曲げ振動の固有振動数 $f_{1}$ と, 式 (6)に示す両端自由はりの理論式の比較か

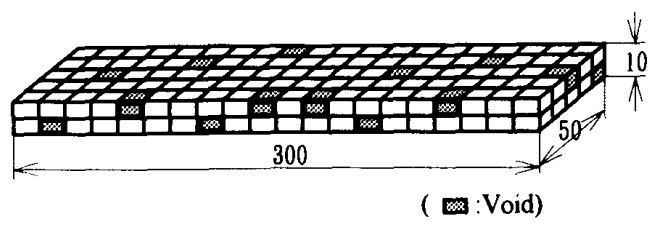

図 7 不規則空孔のあるFEM はりモデル

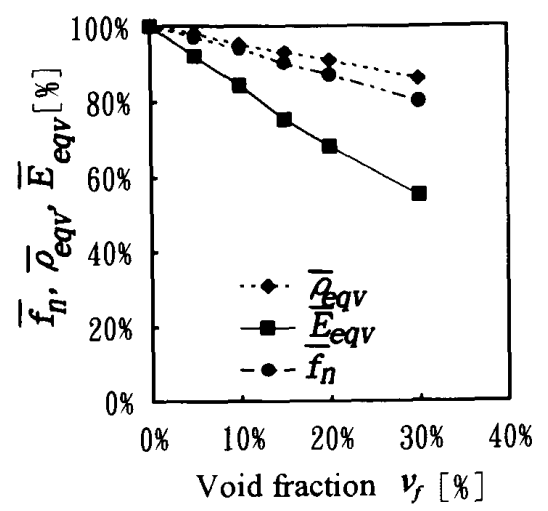

図 8 はりモデルの空孔率と等価パラメータ 
ら, 式( 7 )により算出した。

$$
\begin{aligned}
& f_{1}=\frac{\lambda_{1}^{2}}{2 \pi} \cdot \frac{1}{l^{2}} \sqrt{\frac{E I}{\rho A}}, \lambda_{1}=4.730 \\
& E_{\text {eq } v}=\left(2 \pi \cdot f_{1}\right)^{2} \cdot\left(\frac{l}{\lambda_{1}}\right)^{4} \cdot \frac{\rho_{\text {eq } v A}}{I}
\end{aligned}
$$

ここに, $l, E I, \rho A$ はそれぞれはりの長さ, 曲げ剛性, 単位長さの質量である。

図 8 に空孔率に対する等価密度, 等価ヤング率の変 化を示す.なお, 図では初期の值で除して変化を百分 率で示した(記号の一は無次元化を表す). 空孔率の増 加に伴い等価密度, ヤング率は減少傾向を示すが, ヤ ング率のほうが減少割合が大きいことがわかる。

$4 \cdot 3$ けい骨モデルによる骨粗しょう症シミュレー ション $4 \cdot 2$ 節で求めた等価密度, 等価ヤング率を 用いて, けい骨モデルの FEM 解析を行い, 伝達関数 を求めてサークルフィットから評価值を同定した。 な お伝達関数作成の際には，図 5 に示したように生体の 場合と同じく, 加振点をくるぶし(踝)，応答点をけい 骨代表長さの $1 / 2$ の位置とした，減衰についてはレン トゲン撮影を行った被験者の動特性を参考にした，図

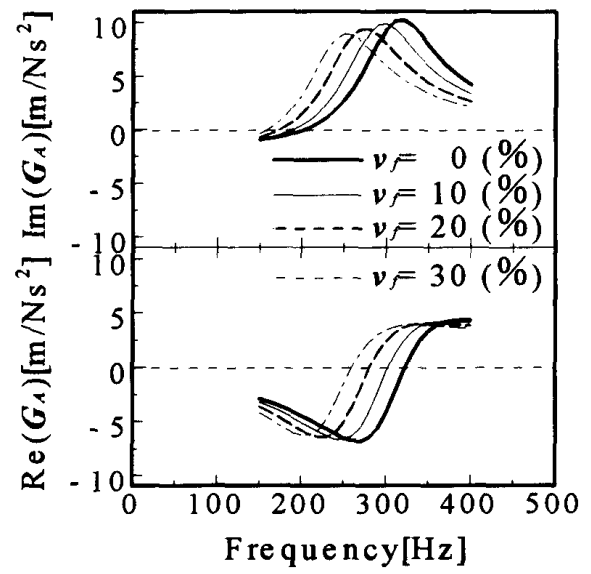

図 9 空孔率によるけい骨 FEM モデル・アクセレランスの 変化

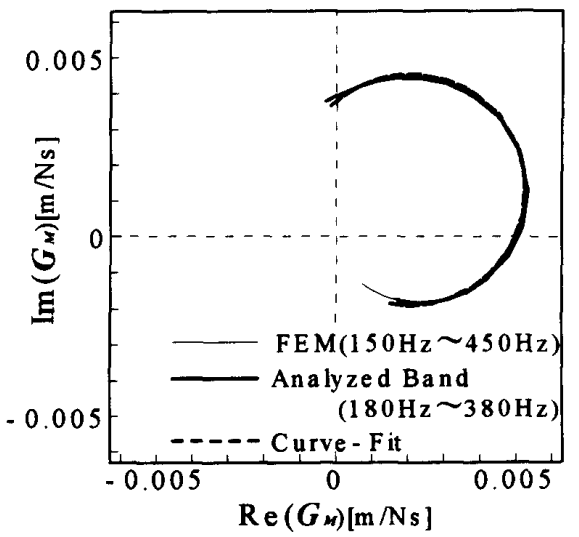

図 10 けい骨 FEM モデルのモビリティ・ナイキスト線図 $\left(v_{f}=10 \%\right)$
9 に空孔率 $v_{f}$ に対するアクセレランスの変化を示 す. 空孔率の増加に伴い固有振動数が低下しているこ とがわかる.図 10 に一例として空孔率 $v_{f}=10 \%$ に対 するサークルフィット結果を示す.図 11 にサークルフ イットにより求めた空孔率に対する評価值の変化を示 す.ただし, 図 8 と同じように相対変化で示した. 空孔 率の増加に伴い固有振動数, 剛性ともに減少の傾向を 示すが, 剛性のほうが隇少割合が大きいことがわか る.またこれら質量, 剛性の空孔率に対する変化は, 図 8 に示した均一断面はりの等価密度, 等価ヤング率 の変化とほほ同じである。これらの結果から, 骨の動 解析により得られる評価值を用いた骨組織劣化の推定 がある程度可能であることが予想される。なお, 評価 值のなかでは, 固有振動数に比べると剛性のほうがよ り組織劣化に敏感であることがわかる.

4・4けい骨長さによる補正評価值(固有振動数 $f_{n}$, 剛性 $k$ ) はけい骨長さ $L$ の影響を受ける.そこでけ い骨長さによる, 補正を均一断面はりの理論より次式 のように行った.

$$
\begin{aligned}
& f_{n}^{*}=f_{n} \cdot L^{2} \cdot \\
& k^{*}=k \cdot L^{3} .
\end{aligned}
$$

補正值 $f_{n}^{*}, k^{*}$ の妥当性を確認するため図 5 に示した

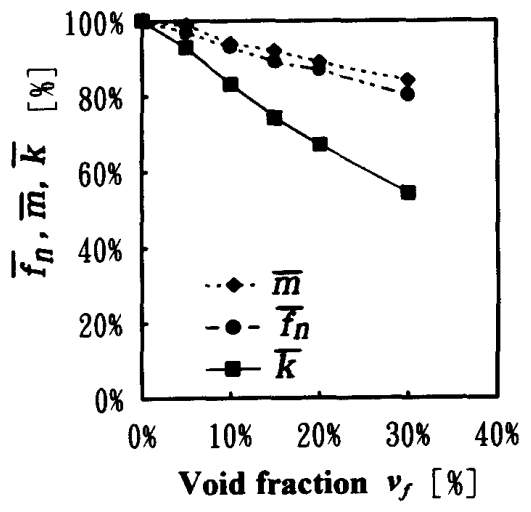

図 11 けい骨モデルの空孔率と評価值パラメータ

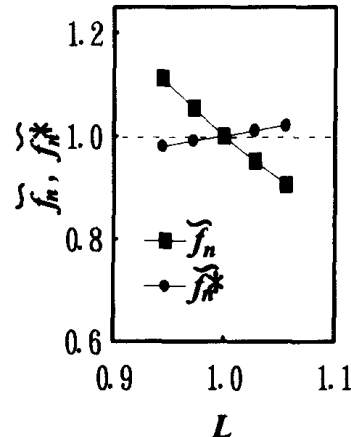

(a) 固有振動数

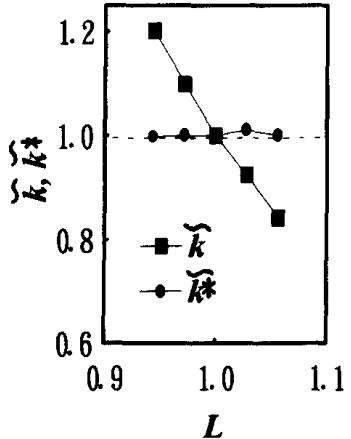

（b）甽性 
けい骨 FEM モデルにおいて，断面積を変化させずに けい骨軸方向にのみ長さを変化させたモデルを作成し て FEM 解析を行った. 図 12(a)，（b ）にけい骨代表 長さの変化に対する補正値の変化を示す。なお, 值は 基準の值で除して無次元化して示した（記号の～は無 次元化を表す).代表長さの変化に対して補正值はほほ 一定とみなせ, 長さの影響を補正していることがわか る.

\section{5. 生体による実験}

健常と思われる被験者(年齢 18～86 歳, 男性 104 人, 女性 51 人, 合計 155 人)に対して実験を行い, 評価值 を算出した。なお評価值の再現性は, 同一被験者に対 し 10 回の実験を行った結果, 変動係数 $C V$ 值は固有 振動数で $5.3 \%$, 剛性で $12.6 \%$ あり, 再現性を確認 した. 加振は 30 秒以内で, 加振力は弱く被験者が苦痛 を感ずることは全くない。

解析を進めるに当たり，図 13 に示すように，測定し た伝達関数に明確な共振峰が現れずナイキスト線図上 では複雑な輪郭となり，1自由度系への同定が困難と なるデー夕もあった.これはモードの連成やけい骨周 りの筋肉組織の影響とも考えられるが, 現在のところ

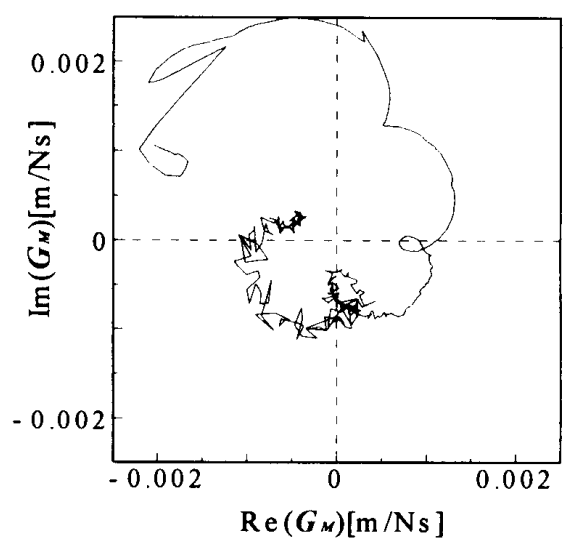

図 13 複雑な形のナイキスト線図

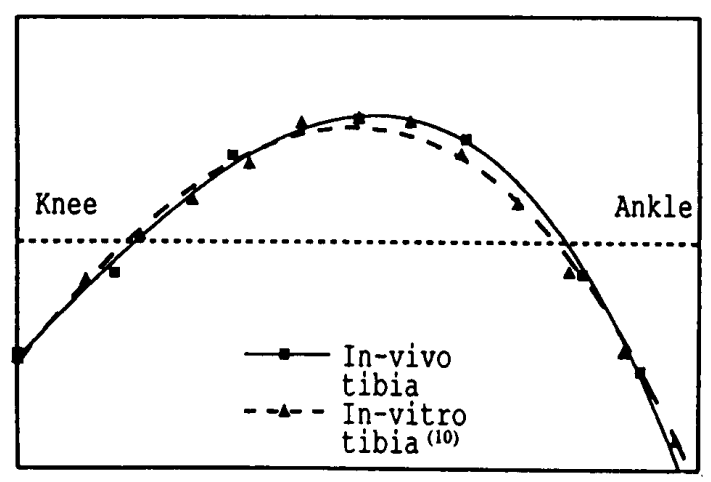

図 14 けい骨の基本モード形
明らかでない．解析が困難であった被験者は全体の約 $22 \%$ あった。ピックアップを移動して計測した振動 モードの例を図14に示す。これは同時に示した Hobatho ${ }^{(10)}$ らの骨単体の両端自由モードとほほ一致 することから, Perre ら(4)(5) も指摘しているように, 生体内における微小振動においてはモードは関節の影 響が少なく両端自由に近い条件にあると推定されるこ とを確認した。図 15,16 に同定された被験者 121 人の 加齢に対する固有振動数, 剛性の分布を示す. 両図と もにかなり值がばらついていることがわかる、ばらつ きの原因としては，骨単体および骨と柔組織との結合 状態などに関する個体差, 生体の非線形性, 加振条件 の不均一性, 他モードの影響などが考えられる. 図中 の直線は傾向をみるため図上で最小二乗をかけた結果 である，加齢に対する傾向では，平均すれば剛性は減 少傾向が認められるが, 固有振動数ではあまり変化が ないといえる.なお, 剛性に対する減少傾向は, 男性で は明確ではないが女性では明確である。同定された固 有振動数は Perre らの報告值 ${ }^{(3)(4)}$ とほほ近い值を示し た. 図 17,18 に長さ補正を行った結果を示した。補正

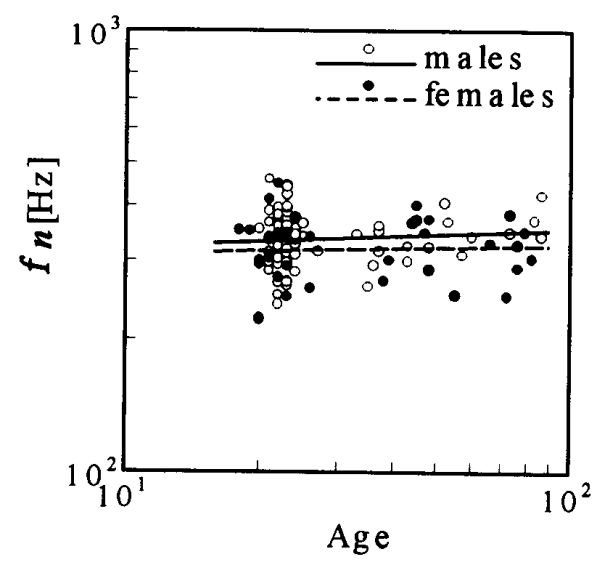

図 15 加齢による固有振動数の変化

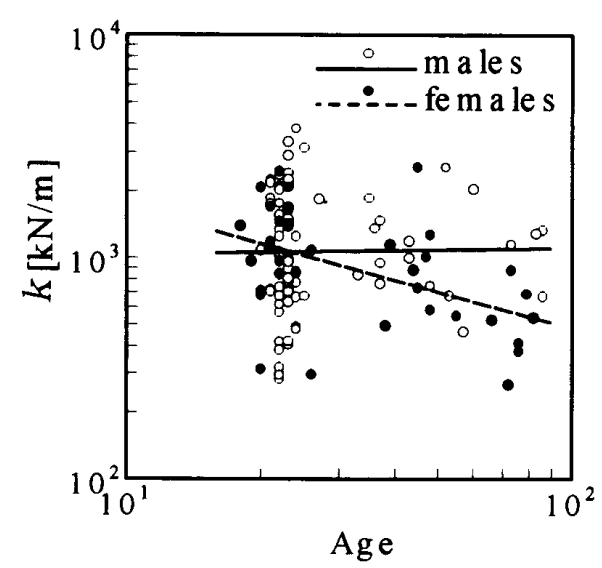

図 16 加齢による剛性の変化 


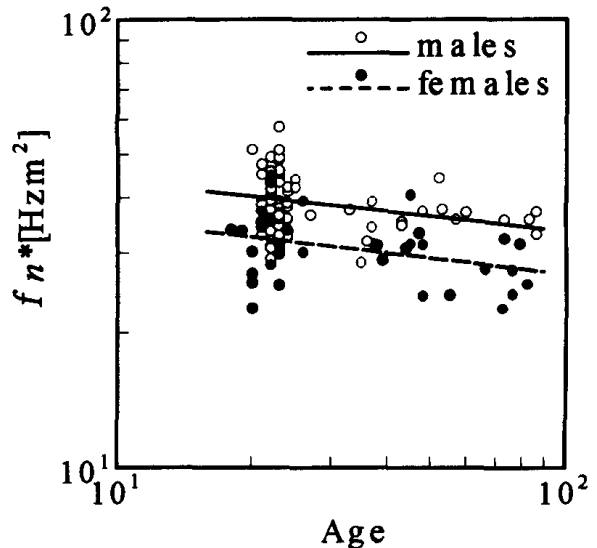

図 17 加此令による補正された固有振動数の変化

された固有振動数, 剛性はばらつきはあるものの加龄 による低下傾向が両者ともに明確に現れ，剛性のほう が固有振動数よりその傾向が強いことがわかる.これ らの結果はシミュレーションの結果と定性的に一致し ているといえる．また，補正された固有振動数の加椧 による低下は Jurist らの尺骨による結果(2) (Jurist ら は $f_{n} L$ の補正を用いている)とも一致している，性に よる違いでみると, 固有振動数, 剖性とも女性のほう が男性に比べて平均的に低い值を示し，また，女性の ほうが加剳による剛性低下の傾向が強いことがわか る.これらの傾向は臨床的な骨量の測定傾向と一致す る(1).

以上，実験的に得られた結果はデータ例，特に高㱓 者例，が少なく，また值がばらついているなど不十分 な点もあるが，シミュレーション結果および過去の報 告例との整合性からみて，ほほ生体内けい骨の動特性 を表しているものと思われる。

\section{6. 結}

本研究は, 生体内骨の劣化に対する直接的評価法と して, 体外から骨を加振し，その動特性解析を利用す る方法を検討するため，けい骨を対象に FEM 解析お よび生体による実験解析を行ったものである。

研究結果をまとめると以下のとおりである.

（1）動特性解析としては，けい骨端部くるぶし (踝)を加振し，けい骨中央部の加速度を計測すること によりモビリティ伝達関数を求め, サークルフィット 法により一次曲げモードを 1 自由度系にモデル化し， 評価値として固有振動数, 俨性を求める方法を用い た。

（2）FEM 解析では，けい骨を骨質分布を考虑し た三次元要素でモデル化し，皮質骨の多孔質化による 評価値の変化を調べる骨粗しょう症シミュレーション

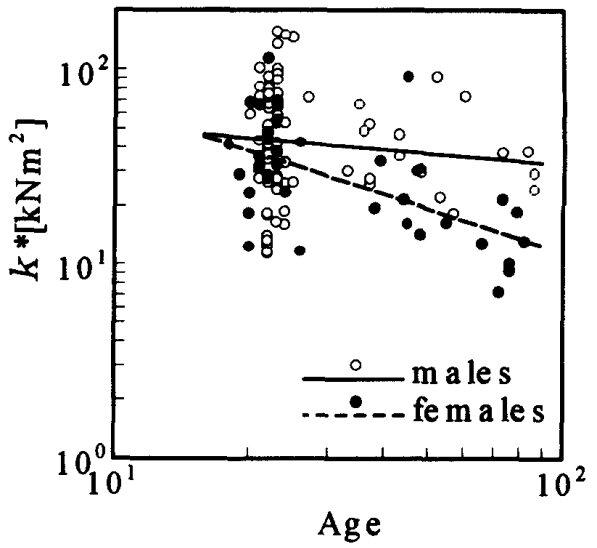

図 18 加龄による補正された网性の変化

を行った.その結果，骨の多孔質化に伴い㷒性，固有振 動数とも低下するが, 剛性の変化は固有振動数の変化 より顕著であること，また剛性の低下は多孔質化に伴 う骨質ヤング率の低下割合とよく一致することがわか った.このことより，骨組織の劣化の評価值としては 固有振動数より棡性を評価するほうが有効であるとい える、また，骨長の補正の妥当性を確認した。

（3）生体の実験ではランダム波加振により動特性 解析を行った。被験者 155 人のうち約 8 割は動特性解 析が可能であったが, 約 2 割は困難であった。骨長に よる補正を行った固有振動数, 剛性はばらつきがある が平均的傾向としてはともに加瑹による低下傾向を示 し，特に剛性のほうがその傾向が強く現れた。また，女 性は男性に比べて評価値が全般的に低く，剛性の加皊 による低下も男性に比して大きい結果が得られた。こ れらの傾向はシミュレーションや他の条件での報告例 と一致し，一般的な骨の加龄による特性を検出してい ると思われる。

最後に, 查読委員の有益なるご教示に感謝する。

\section{文献}

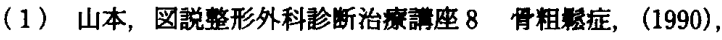
84, メジカルビュー社.

(2) Jurist, J. M., In-Vivo Determination of the Elastic Respons of Bone I, II, Phy. Med. Biol., 15-3 (1970), 417.

(3) Doherty, W. P., Evalution of the Use of Resonant Frequencies to Characterize Physical Properties of Human Long Bones, J. Biomech., 7 (1974), 559.

(4) Perre, G. V., Audekercke, R. V., Martens, M. and Mulier, J.C., Identification of In-Vivo Vibration Modes of Human Tibiae by Modal Analysis, Trans. ASME, J. Biomech. Eng., 105(1993), 244.

(5) Cornelissen, P., Cornelissen, M. and Perr, G. V., Assesment of tibial stiffness by vibration testing in situ-II, 19-7(1986), 551.

(6) Ziegert, J. C. and Lewis, J. L., The Effect of Soft Tissue 
on Measurements of Vibrational Bone Motion by SkinMounted Accelerometers, Trans. ASME, J. Biomech. Eng., 101 (1979), 218.

(7) Nokes, L., Fairclought, J. A., Mintowt-Czyz, W. J., Mackie, I. and Williams, J., Vibration Analysis of Human tibia, Trans. ASME, J. Biomech. Eng., 6(1983), 223.

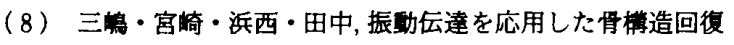

の判定, 日本臨床バイオメカニクス学会誌, 15(1994)，233.

(9) Thomsen, J. J., Modeling Human Tibia Structural Vibrations, J. Biomech., 23(1990), 215.

(10) Hobatho, M. C., Darmana, R., Pastor, P., Barrau, J. J., Laroze, S. and Morucci, J. P., Development of a ThreeDimensional Finite Element Model of a Human Tibia Using Experimental Modal Analysis, J. Biomech., 24-6 (1991), 371. 